\title{
PENINGKATAN KEMAMPUAN KOGNITIF ANAK MELALUI KEGIATAN MEMBILANG BENDA SEKITAR
}

\author{
Hidayat, Eka Cahya Maulidiyah, \\ TK Budi Utomo Lamongan; IAIN Tulungagung \\ Ecahya6 $\overline{4}$ gmail.com
}

\begin{abstract}
Abstrak
Tujuan penelitian ini adalah untuk mengetahui penerapan kegiatan membilang dan peningkatan kemampuan kognitif siswa melalui kegiatan membilang. Penelitian ini dilaksanakan di TK Budi Utomo Lamongan. Penelitian dilaksanakan pada bulan april 2015. Penelitian tindakan (action research) ini menggunakan metode Kemmis dan Mc Taggart, melalui dua siklus yang tediri dari siklus I dan siklus II yang meliputi tahap perencanaan, tindakan, observasi dan refleksi. Subyek penelitian adalah 15 anak Kelompok B TK Budi Utomo Lamongan yang berusia 5-6 tahun. Data diperoleh dengan berpedoman pada lembar observasi kemampuan kognitif konsep bilangan dan lambang bilangan. Hasil penelitian ini menunjukkan adanya peningkatan kemampuan kognitif anak yang dibuktikan pada perolehan skor kemampuan kognitif rata-rata siswa. Sebelum penelitian skor rata-rata adalah $60.4 \%$. Setelah dilaksanakan siklus I terjadi perubahan skor kemampuan kognitif rata-rata kelas menjadi 85.9\%. Pada siklus II perubahan skor kemampuan kognitif rata-rata kelas menjadi 97.04\%. Pada siklus II seluruh siswa telah memenuhi kriteria kesuksesan sehingga penelitian ini dicukupkan dengan pelaksanaan dua siklus.
\end{abstract}

Katakunci: kemampuan kognitif, kegiatan membilang

\begin{abstract}
The research is aimed at determining the application of calculation activities and the increase of students' cognitive skill through the activity. The research was carried out in TK Budi Utomo Lamongan in April 2015. This action research applied method proposed by Kemmis and McTaggart using two cycles, cycle I and II, involving the stages of plan, action, observation, and reflection. Subjects of the research are 15 students of group B in TK Budi Utomo Lamongan at the age of 5-6 years old. The data was obtained from the observation's field note on cognitive skills upon numeral concept and symbol. The research result showed an increase on the students' cognitive skills proved by the students' average scores in cognitive skill achievement. The average score before the treatment was $60.4 \%$. After treatment in cycle I there was a change to the average of their cognitive skills into $85.9 \%$. In the cycle II the average of students' cognitive skill rose into $97.04 \&$. All of the students had passed the minimum criteria in cycle II thus the research was considered acceptable after the two cycles.
\end{abstract}

Keywords: cognitive skill, calculation activity

\section{PENDAHULUAN}

Peneliti merupakan guru di kelompok B TK Budi Utomo Lamongan peneliti mengamati kemampuan kognitif anak yang seharusnya dapat berkembang secara optimal melalui pembelajaran ternyata masih terlihat belum maksimal.
Peneliti mengamati sekitar 40\% kemampuan kognitif anak belum maksimal. Belum maksimalnya kognitif anak dapat terjadi akibat proses pembelajaran masih banyak terfokus pada guru serta pendekatan yang belum sesuai. Sehingga dibutuhkan sebuah kegiatan yang mampu meningkatkan kemampuan kognitif anak. 
Kegiatan yang dipilih haruslah mendukung kemampuan kognitif yang telah ada pada diri setiap anak sejak usia dini. hala tersebut akan membuat kemampuan kognitif anak dapat terasah sejak dini dan anak tidak mendapatkan kesulitan pada jenjang pendidikan yang lebih tinggi serta dalam kehidupannya ketika dewasa. Salah satu alternatif kegiatan yang dapat digunakan untuk meningkatkan kemampuan kognitif anak adalah kegiatan membilang benda sekitar. Kegiatan membilang benda sekitar yang dilakukan memperhatikan prinsip perkembangan dan karakteristik anak usia dini diupayakan membangun gagasan untuk mengekspresikan kebebasan, imajinasi, dan kreativitas sehingga dapat mengembangkan aspek-aspek perkembangan anak usia dini salah satunya perkembangan kognitif.

Proses pembelajaran yang dilakukan melalui kegiatan membilang disajikan dengan membuat suasana bermain menjadi menyenangkan dan menarik minat anak. Suasana yang demikian diharapkan menjadikan pembelajaran menantang bagi anak sehingga anak mudah membangun pengetahuannya sendiri. Tahapan-tahapan dalam menemukan dan membangun pengetahuan melalui proses berpikir yang sistematis serta melalui benda konkret diharapkan membuat kemampuan kognitif anak dapat meningkat.

Melalui pernyataan-pernyataan di atas maka peneliti tertarik meneliti kegiatan membilang untuk meningkatkan kemampuan kognitif anak. Diharapkan melalui kegiatan ini akan tercipta suasana yang menyenangkan bagi anak. Dari kondisi tersebut koneksi neuron anak akan dapat tersambung secara terus-menerus sehingga akan dapat memicu anak untuk berpikir sistematis dan imajinatif sehingga pembelajaran dapat maksimal di TK Budi Utomo Lamongan.

Tujuan penelitian ini adalah mendeskripsikan penerapan kegiatan membilang benda sekitar untuk meningkatkan kemampuan kognitif anak di kelompok B TK Budi Utomo Lamongan, dan mengetahui apakah kegiatan membilang benda sekitar dapat meningkatkan kemampuan kognitif anak di kelompok B TK Budi Utomo Lamongan.

Perkembangan kognitif meliputi perubahan pada aktivitas mental yang berhubungan dengan persepsi, pemikiran, ingatan, keterampilan berbahasa dan pengolahan informasi yang memungkinkan seseorang memperoleh pengetahuan, memecahkan masalah, dan merencanakan masa depan, atau semua proses psikologis yang berkaitan dengan bagaimana individu dapat mempelajari, memperhatikan, lalu mengamati, membayangkan, memperkirakan, menilai dan memikirkan lingkungannya (Desmita. 2009 :34).

Pendekatanpendekatan perkembangan kognitif menekankan pada cara anak secara aktif membangun pikirannya. Pendekatan tersebut juga sangat berfokus pada cara berpikir anak yang berubah dari satu titik perkembangan ke titik perkembangan berikutnya. Proses yang digunakan anak ketika membangun pengetahuan mereka mencakup skema, asimilasi, akomodasi, organisasi, keseimbangan, dan penyeimbang (Santrock. 2002).

Piaget menyatakan bahwa setiap individu mengalami empat tahapan perkembangan yang berhubungan dengan usia anak yang bersangkutan dan terdiri atas cara-cara pemikiran yang unik. Adapun keempat tahapan tersebut meliputi; 1) tahapan sensorimotor, 2) tahapan praoperasional, 3) tahapan operasional konkrit, dan 4) tahapan operasional formal (Santrock, 2002)

pada usia 2-7 tahun, pada tahap ini anak mempunyai gambaran mental dan mampu untuk berpura-pura, langkah pendek untuk menggunakan symbol (Sujiono, 2004: 3.11). Fase praoperasional dapat dibagi ke dalam tiga sub fase, yaitu subfase fungsi simbolis, subfase berpikir egosentris, dan subfase berpikir intuitif (Jamaris, $2006: 21$ ). Subfase fungsi simbolis terjadi pada usia 2-4 tahun. Pada masa ini, anak telah memiliki kemampuan untuk menggambarkan suatu 
objek yang secara fisik tidak hadir, misal anak menyusun balok-balok kecil untuk membuat rumah-rumahan. Subfase berpikir egosentris terjadi pada usia 2-4 tahun. pada masa ini, anak tidak mampu memahami perspektif atau cara berpikir orang lain. Benar atau salah ditentukan oleh cara pandangnya sendiri. Subfase berpikir intuitif terjadi pada usia 4-7 tahun, pada masa ini, anak belum mampu untuk berpikir secara kritis tentang apa yang ada dibalik suatu kejadian.

Adapun indikator kemampuan kognitif anak usia 5-6 tahun akan mengacu dengan Standart Pendidikan Anak Usia Dini dengan lingkup perkembangan yang akan dikembangkan dalam penelitian ini adalah konsep bilangan dan lambang bilangan. Indikator kemampuan kognitif anak usia 5-6 tahun tentang konsep bilangan dan lambang bilangan yang dimaksud adalah berjumlah 6 indikator antara lain: menyebut urutan bilangan satu sampai sepuluh, menghitung jumlah benda (1-10), membedakan benda berdasarkan jumlahnya, menunjuk lambang bilangan 1-10, mencocokkan jumlah benda dengan lambang bilangan, menunjuk angka yang sesuai dengan jumlah benda.

menurut Yus (2011: 70) membilang merupakan salah satu hal yang digunakan untuk memahami dasar-dasar operasional yang berhubungan dengan logikamatematika. Kegiatan membilang pada anak usia dini difokuskan pada hal-hal terdekat dan konkret bagi anak sesuai dengan karakteristik anak yang belajar dari konkret ke abstrak dan dari dekat ke jauh. Berdasarkan pernyataan di atas maka kegiatan membilang didefinisikan merupakan kegiatan menyebut satu persatu untuk menghitung jumlah benda sebagai dasar untuk memahami dasar-dasar operasional.

Kegiatan membilang memiliki beberapa variasi yang dapat digunakan untuk mengajarkan anak akan konsep bilangan dan lambang bilangan antara lain yang dikemukakan oleh Ipiet (2014)membilang dengan jari, membilang benda-benda, membilang sambil berolahraga, membilang sambil bernyanyi, membilang di atas sepuluh. Selain beberapa kegiatan diatas kegiatan membilang juga dapat dilakukan melalui benda-benda konkrit yang biasanya dapat ditemui dengan mudah di tempat bermain anak di sekolah maupun di rumah sepert menggunakan balok atau biji-bijian. Hal penting yang harus diperhatikan ketika melakukan kegiatan ini adalah merencanakan dengan jelas dan memastikan tempat yang aman dan nyaman untuk anak melakukan kegiatan, sehingga peneliti dan guru dapat dengan mudah mengamati anak.

Berdasarkan latar belakang masalah yang telah disajikan pada diketahui bahwa kemampuan kognitif anak yang berkaitan dengan cara anak membangun pengetahuannya melalui lingkungan haruslah diajarkan melalui kegiatan membilang disajikan dengan membuat suasana bermain menjadi menyenangkan dan menarik minat anak.

Suasana yang demikian diharapkan menjadikan pembelajaran menantang bagi anak sehingga anak mudah membangun pengetahuannya sendiri. Tahapan-tahapan dalam menemukan dan membangun pengetahuan melalui proses berpikir yang sistematis serta melalui benda konkret diharapkan membuat kemampuan kognitif anak dapat meningkat.

\section{METODE PENELITIAN}

Metode yang dilakukan berrdasarkan tujuan penelitian dan latar belakang penelitian ini, maka jenis penelitian yang sesuai adalah penelitian tindakan kelas. Penelitian tindakan ini bersifat partisipatif dan kolaboratif. Partisipatif dalam artian peneliti akan mendesain pembelajaran dan ikut serta dalam pembelajaran sebagai pemberi perlakuan serta ikut mengobservasi selama kegiatan berlangsung. Sementara guru pendamping kelas akan turut mengobservasi. Hasilnya akan dievaluasi bersama secara kolaborasi guru pendamping dan peneliti.

Dalam penelitian ini menggunakan pendekatan kualitatif dan kuantitatif. 
Pendekatan kualitatif menjelaskan peristiwa yang dilakukan dalam penelitian ini sehingga mendapatkan gambaran dan penjelasan yang lengkap dalam pelaksanaan penelitian tindakan. Pendekatan kuantitatif digunakan untuk menganalisis data hasil proses belajar mengajar atau membandingkan nilai peserta didik sebelum dan sesudah penelitian tindakan dilakukan.

Penelitian ini menggunakan desain penelitian model Kemmis dan Taggart dimana setiap siklusnya mengikuti langkahlangkah sistematis sesuai dengan kaidahkaidah penelitian. Tahapan-tahapan penelitian dalam model Kemmis dan Taggart meliputi: (1) perencanaan (planning), (2) tindakan (action), (3) pengamatan (observation), dan (4) refleksi (reflection) (Akbar, 2009:30).

Kriteria keberhasilan dalam tindakan dalam penelitian ini ditentukan berdasarkan kesepakatan antara peneliti dan kolaborator yaitu sebesar 71\%. Kriteria keberhasilan tersebut sesuai dengan yang disampaikan oleh Mills dimana keberhasilan tindakan yang dimaksud dalam penelitian ini yaitu apabila rata-rata kelas telah mencapai minimal 71\% (Mills, 2000:96). Jika perolehan prosentase dalam penelitian ini kurang dari $71 \%$ maka penelitian akan dilanjutkan pada siklus II. Kemudian Suharsimi menggolongkan prosentase dalam kategori sebagai berikut: $\quad 40 \%$ (tidak baik); 40\% - 55\% (kurang baik); 56\% - 75\% (cukup); 76\% - 100\% (baik).

Kolaborator yang terlibat yaitu guru kelas pendamping dan kepala sekolah. Penelitian tindakan kelas ini dilaksanakan di TK Budi Utomo Pendowolimo, Karangbinangun, Kabupaten Lamongan, Jawa Timur. Alasan dilakukannya penelitian di tempat ini adalah peneliti menemukan di Kelompok B TK Budi Utomo Lamongan kemampuan kognitif anak yang seharusnya dapat berkembang secara optimal melalui pembelajaran ternyata masih terlihat belum maksimal. Peneliti sebagai guru di TK Budi Utomo mengamati sekitar 41\% kemampuan kognitif anak belum maksimal. Belum maksimalnya kemampuan kognitif anak dapat terjadi

akibat proses pembelajaran masih banyak terfokus pada guru serta pendekatan yang belum sesuai.

Berdasarkan pernyataan di atas maka digunakanlah kegiatan membilang dengan menggunakan benda sekitar dengan media yang konkret, dekat dengan lingkungan anak dan menarik bagi anak untuk meningkatkan kemampuan kognitif anak. Hal tersebut disesuaikan dengan karakteristik dan prinsip-prinsip perkembangan anak. Subyek penelitian adalah siswa kelompok B TK Budi Utomo yang memiliki rentang usia 5-6 tahun dan berjumlah 15 orang dengan rincian 10 siswa perempuan dan 5 siswa laki-laki. Peneliti adalah guru sekaligus pemberi perlakuan dan pengamat pelaksanaan kegiatan.

\section{HASIL PENELITIAN}

Penelitian dilakukan selama 2 siklus yaitu pada bulan April 2015. Penentuan waktu mengacu pada kalender pendidikan, tema dan kurikulum karena membutuhkan proses pembelajaran yang efektif dan saling terintegrasi. Dalam prosedur penelitian ini akan dibahas mengenai tahapan dalam melakukan penentian tindakan kelas antara lain: studi pendahuluan atau observasi awal, perencanaan, kemudian pelaksanaan, pengamatan atau observasi, dan refleksi.

Observasi awal dilakukan pada bulan maret 2015. Sebagai guru di kelompok B TK Budi Utomo Lamongan peneliti mengamati kemampuan kognitif anak yang seharusnya dapat berkembang secara optimal melalui pembelajaran ternyata masih terlihat belum maksimal. Peneliti mengamati rata-rata kemampuan kognitif anak belum maksimal pada konsep bilangan dan lambang bilangan. Berkaitan belum maksimalnya kemampuan kognitif anak dapat terjadi akibat proses pembelajaran masih banyak terfokus pada guru serta pendekatan yang belum sesuai. Sehingga dibutuhkan sebuah kegiatan yang mampu meningkatkan kemampuan kognitif anak. 
Perencanaan dalam penelitian tindakan meliputi penentuan indikator per pertemuan, pembuatan $\mathrm{RKH}$, penyediaan media benda-benda sekitar dan mensetting ruangan sesuai keadaan yang diperlukan oleh peneliti. Perencanaan juga dimuat jadwal pertemuan untuk mempermudah dalam observasi.

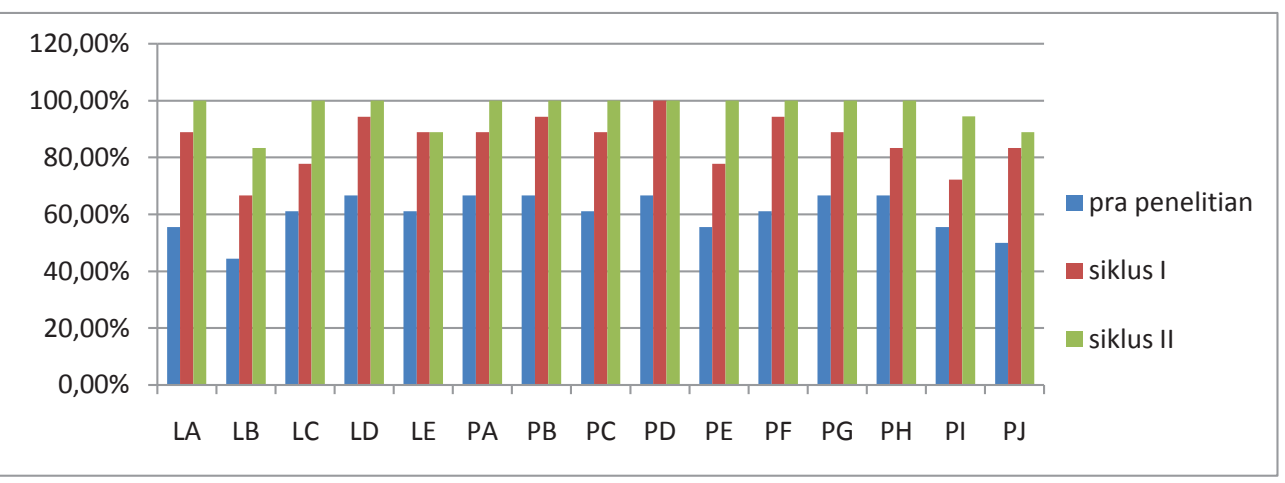

Gambar 1

Perbandingan Skor Pra Penelitian, Siklus I dan Siklus II

Berdasarkan gambar di atas, peningkatan kemampuan kognitif secara kuantitatif dapat dilihat dari perubahan skor kemampuan kognitif siswa pada pra penelitian, siklus I dan siklus II yang signifikan. Pada pra penelitian skor kemampuan kognitif rata-rata siswa adalah $60.4 \%$ dengan kategori siswa berada kategori kurang baik dan cukup, skor pra penelitian tersebut belum memenuhi kriteria kesuksesan yang telah disepakati yakni sebesar $71 \%$.

Hal tersebut memiliki arti bahwa kemampuan kognitif anak dalam hal konsep bilangan dan lambang bilangan perlu ditingkatkan untuk mencapai perkembangan yang maksimal. Skor tertinggi adalah $66.7 \%$ yang diperoleh oleh 6 siswa yakni siswa LD, PA, PB, PD, PG, PH. Dalam observasi atau pengamatan peneliti selama pra observasi 6 siswa tersebut menunjukkan kemampuan yang cukup dalam hal pemahaman konsep bilangan dan lambang bilangan dan hanya memerlukan bantuan dalam hal-hal tertentu. Skor terendah adalah 44,4\% diperoleh oleh siswa LB. Siswa LB berdasarkan pengamatan peneliti selama pra observasi memang memiliki kesulitan terutama dalam hal mengingat urutan bilangan dan lambang bilangan sehingga memerlukan bantuan yang lebih banyak dibandingkan temanteman yang lain.

Pada siklus I terjadi perubahan setelah dilaksanakan siklus I skor kemampuan kognitif rata-rata kelas menjadi $85.9 \%$ hal tersebut berarti terjadi peningkatan sebesar $25.56 \%$ dan sebagian peserta telah memenuhi kriteria kesuksesan diatas $71 \%$. Hanya terdapat satu siswa yang belum memenuhi atau hampir memenuhi kriteria kesuksesan. Hal tersebut memiliki arti bahwa kemampuan kognitif anak dalam hal konsep bilangan dan lambang bilangan telah meningkat setelah melakukan kegiatan membilang dengan berbagai metode dan berbagai media yang telah dilaksanakan di siklus I.

Skor tertinggi adalah 100\% yang diperoleh oleh siswa PD. Dalam observasi atau pengamatan peneliti selama siklus I siswa tersebut menunjukkan kemampuan yang baik dalam hal pemahaman konsep bilangan dan lambang bilangan sehingga terkadang peneliti melihat PD juga membantu teman untuk menyebut urutan bilangan dengan benar. Skor terendah adalah $66,7 \%$ diperoleh oleh siswa LB. Siswa LB berdasarkan pengamatan peneliti 
selama siklus I telah menunjukkan peningkatan dalam perkembangan kognitif, namun tidak begitu signifikan dibanding teman-temannya yang lain. Hal tersebut dikarenakan LB adalah anak yang pemalu sehingga untuk bermain secara kelompok belum memiliki antusias seperti temanteman yang lain.

Pada siklus II perubahan skor kemampuan kogntiif rata-rata kelas menjadi 97.04\% hal tersebut berarti terjadi peningkatan sebesar $11.11 \%$. Pada siklus II seluruh siswa telah memenuhi kriteria kesuksesan sehingga penelitian ini dicukupkan dengan pelaksanaan dua siklus. Pada siklus II diketahui bahwa skor ratarata siswa sudah memenuhi kriteria kesuksesan minimal yakni sebesar 71\%. Hal tersebut memiliki arti bahwa kemampuan kognitif anak dalam hal konsep bilangan dan lambang bilangan telah meningkat setelah melakukan kegiatan membilang dengan berbagai metode dan berbagai media yang telah dilaksanakan di siklus I.

Skor tertinggi adalah $100 \%$ yang diperoleh oleh 11 siswa. Dalam observasi atau pengamatan peneliti selama siklus II siswa-siswa tersebut menunjukkan kemampuan yang baik dalam hal pemahaman konsep bilangan dan lambang bilangan. Hasil penelitian tersebut menunjukkan perubahan peningkatan skor kemampuan kognitif baik secara individu maupun rata-rata kelas telah memenuhi kriteria kesuksesan dan dinyatakan berhasil.

Langkah selanjutnya adalah menggolongkan prosentase dalam kategori sebagai berikut: $40 \%$ (tidak baik); 40\% $55 \%$ (kurang baik); 56\% - 75\% (cukup); $76 \% \quad-\quad 100 \% \quad$ (baik). Berdasarkan penggolongan prosentase tersebut maka akan diketahui perbedaan baik secara individu maupun rata-rata prosentase skor hasil pra observasi, siklus I, dan pada siklus II. Penggolongan tersebut dapat dilihat melalui tabel kategori skor pra penelitian, siklus I dan siklus II sebagai berikut :

Tabel 1. Kategori Skor Hasil Pra Penelitian, Siklus I, dan Siklus II

\begin{tabular}{|c|c|c|c|c|}
\hline Kategori & Skor & Pra penelitian & Siklus I & Siklus II \\
\hline Tidak baik & $40 \%$ & - & - & - \\
\hline Kurang baik & $40 \%-55 \%$ & LB, PJ & - & - \\
\hline Cukup & $56 \%-75 \%$ & $\begin{array}{l}\text { LA, LC, LD, } \\
\text { LE, PA, PB, } \\
\text { PC, PD, PE, } \\
\text { PF, PG, PH, PI }\end{array}$ & LB, PI & - \\
\hline Baik & $76 \%-100 \%$ & & $\begin{array}{l}\mathrm{LA}, \mathrm{LC}, \mathrm{LD}, \\
\mathrm{LE}, \mathrm{PA}, \mathrm{PB}, \\
\mathrm{PC}, \mathrm{PD}, \mathrm{PE}, \\
\mathrm{PF}, \mathrm{PG}, \mathrm{PH}, \mathrm{PJ}\end{array}$ & $\begin{array}{l}\text { LA,LB, LC, LD, } \\
\text { LE, PA, PB, PC, } \\
\text { PD, PE, PF, PG, } \\
\text { PH, PI, PJ }\end{array}$ \\
\hline
\end{tabular}

Dari tabel diatas maka dapat diketahui pada pra penelitian, 2 siswa berada pada kategori kurang baik dan 13 siswa pada kategori cukup. Kategori perkembangan kemampuan kognitif yang baik berdasar kriteria kesuksesan dan kategori skor diatas maka siswa seharusnya berada pada prosentase di atas $71 \%$ dan berada pada kategori baik. Pada siklus I, 2 siswa berada pada kategori cukup dan 13 siswa pada kategori baik. Kategori perkembangan kemampuan kognitif yang baik berdasar kriteria kesuksesan dan kategori skor diatas maka mayoritas siswa telah berada pada prosentase di atas 75\% dan berada pada kategori baik. Pada siklus II dapat diketahui seluruh anak berada pada kategori baik, dari kategori tersebut maka dapat disimpulkan secara keseluruhan kemampuan kognitif anak telah memenuhi kriteria kesuksesan yang telah ditetapkan. Maka pada siklus II ini pelaksanaan penelitian telah dicukupkan dan peneliti 
langsung membuat analisis serta laporan penelitian yang dilakukan dalam dua siklus.

\section{SIMPULAN}

Berdasarkan hasil penelitian dan pembahasan pada penelitian tindakan yang berjudul Meningkatkan Kemampuan Kognitif melalui Kegiatan Membilang pada Kelompok B TK Budi Utomo Lamongan maka dapat disimpulkan sebagai berikut:

Penerapan kegiatan membilang untuk meningkatkan kemampuan kognitif kelompok B TK Budi Utomo Lamongan dilaksanakan dengan menggunakan berbagai variasi kegiatan (bermain, menyanyi, berlomba dan bertepuk) dan variasi media (jari, balok, biji jagung, dan kelereng). Kegiatan tersebut dilaksanakan sesuai dengan karakteristik anak dan lingkungan sekitar anak.

Terdapat peningkatan pada kemampuan kognitif anak melalui kegiatan membilang pada kelompok B di TK Budi Utomo Lamongan. Hal tersebut dibuktikan dengan peningkatan skor kemampuan kognitif siswa pada pra penelitian skor kemampuan kognitif rata-rata siswa adalah $60.4 \%$. Setelah dilaksanakan siklus I terjadi perubahan skor kemampuan kognitif ratarata kelas menjadi $85.9 \%$ hal tersebut berarti terjadi peningkatan sebesar $25.56 \%$. Pada siklus II perubahan skor kemampuan kogntiif rata-rata kelas menjadi 97.04\% hal tersebut berarti terjadi peningkatan sebesar $11.11 \%$. Pada siklus II seluruh siswa telah

\section{DAFTAR PUSTAKA}

Akbar, Sa'dun. 2009. Penelitian Tindakan

Kelas : Filosofi, Metodologi,

Implementasi Yogyakarta:Cipta Media.

Desmita. 2009.Psikologi Perkembangan

Peserta Didik. Bandung: Remaja

Rosdakarya,

Ipiet. 2014. Membilang Pada Anak Usia

Dini http://duniaanakbalita.blogspo memenuhi kriteria kesuksesan sehingga penelitian ini dicukupkan dengan pelaksanaan dua siklus.

\section{SARAN}

Berdasarkan kesimpulan diatas, maka saran yang dapat diberikan pada penelitian yang berjudul Meningkatkan Kemampuan Kognitif melalui Kegiatan Membilang pada Kelompok B TK Budi Utomo Lamongan adalah sebagai berikut:

Melalui penelitian ini diharapkan guru akan lebih aktif dalam memberikan pembelajaran yang menarik dan membuat anak aktif dalam kegiatan maupun dalam mengemukakan pendapat. Mulailah dengan kegiatan dan media yang dekat dengan anak salah satunya sseperti dalam penelitian ini menggunakan kegiatan membilang dengan memanfaatkan media di sekitar anak.

Lembaga TK. Budi Utomo hendaknya terus mengembangkan ide melalui berbagai upaya termasuk penelitian tindakan, baik yang dilakukan oleh guru sendiri maupun melalui bantuan penelitian dari para akademisi atau ahli.

Orangtua adalah juga merupakan komponen terpenting pada pendidikan anak usia dini sehingga orang tua harus memiliki interaksi dan kerjasama yang kuat dengan guru maupun pihak sekolah. Diharapakan dengan adanya penelitian ini agar dapat melanjutkan penelitian ini dalam skala yang lebih besar dan luas serta mendalam. Sehingga dapat dijadikan rujukan dalam pembelajaran pendidikan anak usia dini.

t.com $/ 2014 / 01 / \mathrm{membilang}$-padaanak-usia-dini.html. diakses April 2015

Jamaris, Martini. Perkembangan dan Pengembangan Anak Usia Taman Kanak-kanak. Jakarta:Grasindo, 2006.

Mills, Geoffrey E. 2000. Action Research A Guide For The Teacher 
Researcher. New Jersey: Prentice Hall.

Santrock, J. W. 2002. Life - Span Development Jilid I (Alih Bahasa: Juda Damanik dan Achmad Chusairi). Jakarta: Erlangga.

Sujiono, Yuliani Nurani dan Bambang Sujiono. Seri Mengembangkan
Potensi Bawaan, Persiapan dan Saat Kehamilan. Jakarta: Elek Media Komputindo. 2004.

Yus, Anita. 2011. Model Pendidikan Anak

Usia Dini. Jakarta: Prenada Media Group. 